\title{
praise for eli clare
}

"Using the language of the elemental world, [Eli Clare] delineates a complex human intersection and transmutes cruelty into its opposite - a potent, lifegiving remedy." -Alison Bechdel, creator of Fun Home: A Family Tragicomic and Dykes to Watch Out For

"Eli Clare's Exile and Pride ... challenge[s] us to think beyond identity politics. This set of nine interconnected essays defies categorization in its exploration not only of queerness and disability but also of class, race, urban-rural divides, gender identity, sexual abuse, environmental destruction, and the meaning of home. ... Clare gives us a vision of a broad-based and intersectional politics that can move us beyond the current divisions of single-issue movements."

- Rachel Rosenbloom, The Women's Reviere of Books

"Eli's work detonates inside of you, right to the edges of where you balance."

-Amber L. Hollibaugh, author of My Dangerous Desires: A 2ueer Girl Dreaming Her Way Home

"The books that move us most are the ones that help us make sense of our experience, that take pieces of what we already know and put it together with new insights, new analysis, enabling us to form a fresh vision of ourselves and our lives. For me, Audre Lorde's Sister Outsider and Adrienne Rich's On Lies, Secrets and Silence were such books, and there were significant others along the way. And now there's Eli Clare's Exile and Pride."

-Suzanne Pharr, author of Homophobia: A Weapon of Sexism 

exile E̋ pride 



\section{exile E pride}

\section{disability, queerness, and liberation}

\section{eli clare}

With a new foreword by Aurora Levins Morales and an afterword by Dean Spade 
(C) I999, 2009 Eli Clare

Originally published by South End Press

first edition, I999, second edition, 2009

Republished by Duke University Press, 2015

All rights reserved

Printed in the United States of America on acid-free paper $\infty$

Library of Congress Cataloging-in-Publication Data

Clare, Eli, author.

Exile and pride : disability, queerness, and liberation / Eli Clare.

pages $\mathrm{cm}$

Includes bibliographical references and index.

ISBN 978-0-8223-6oI6-2 (hardcover : alk. paper)

ISBN 978-0-8223-603I-5 (pbk. : alk. paper)

ISBN 978-0-8223-7487-9 (e-book)

I. Clare, Eli. 2. Women political activists - United States-

Biography. 3. Cerebral palsied_-United States_Biography.

4. Transgender people-United States-Biography. I. Title.

HQI426.C56 2015

$306.76^{\prime} 8092-\mathrm{dc} 23$

[B]

20150163I2

Cover art: Photo of a Douglass Fir burl,

North Cascades National Park, Washington.

Danita Delimont / Alamy. 
To the rocks and trees, hills and beaches 